ORIGINAL ARTICLE

\title{
Improving hospital doctors' working lives: online questionnaire survey of all grades
}

\section{A Dornhorst, J Cripps, H Goodyear, J Marshall, E Waters, S-A Boddy on behalf of the Improving Working Lives Intercollegiate Committee}

Postgrad Med J 2005;81:49-54. doi: 10.1136/pgmi.2004.029512

See end of article for authors' affiliations

.....................

Correspondence to: Dr Anne Dornhorst, c/o

The Intercollegiate IWL

Committee, Royal College

of Surgeons of England,

35-43 Lincoln's Inn Fields,

London WC2A 3PE, UK;

iwl@rcseng.ac.uk

Submitted 7 October 2004 Accepted

15 November 2004

\begin{abstract}
Background: In 2001, the Department of Health produced the Improving Working Lives (IWL) for Doctors document. This is the first national survey which asks hospital doctors what changes are needed to improve their working lives.

Methods: An online questionnaire was run over a period of six weeks and was open to all doctors of all grades. Doctors were asked to choose their top five factors from a list of 35 diverse choices or to provide alternatives in free text. Demographic data were also collected.

Results: 1603 hospital doctors working in the UK completed the online questionnaire. Improved secretarial or managerial support was the first IWL choice for consultants, with different aspects of clinical and nonclinical support representing their top four choices. Junior hospital doctors and staff and associate specialist grades (staff grades, associate specialists, and clinical assistants) identified improved support for education and training as their first choice, while among the female specialist registrars, it was improved support for childcare.

Greater opportunities to develop new skills was an important issue for doctors in the surgical specialties and improved access to mentoring was important for all junior doctors, staff and associate specialist grades, and doctors from black and ethnic minority groups.

Conclusions: Hospital doctors in the UK need more support to improve their working lives. The principle needs are better secretarial and managerial support for consultants; education, training, and mentoring for junior doctors and staff and associate specialist grades; and improved opportunities to develop new skills for those in surgical specialties. Support with childcare is an important issue for female specialist registrars. The Department of Health, NHS trusts, deaneries, and Royal Colleges need to endorse policies that promote a training and working environment that will improve working lives for all hospital doctors, ensuring that appropriate and continuing support is available from the time doctors enter the new foundation programmes and proposed run-through grades, to their time spent as consultants in today's NHS.
\end{abstract}

n 2001, the Department of Health published the Improving Working Lives (IWL) for Doctors policy document. ${ }^{1}$ Consequently, all NHS organisations have been required to have policies, practices, and people in place to implement IWL initiatives locally.

Specific IWL standards and performance targets are now an integral part of the NHS Plan. NHS organisations will need to achieve these IWL standards by 2006 in order to obtain "Practice Plus" IWL status.

Practice Plus status would indicate that an NHS organisation has demonstrated, through effective partnership and staff involvement, that the working lives of staff across all staff groups has been improved.

In 2002, a working party "The Intercollegiate IWL Committee" was formed comprising representatives from all medical Royal Colleges, two senior Department of Health human resource managers, and Mr Eric Waters, the IWL Champion for Doctors.

In order to identify which aspects of doctors' working lives needed improving most, the Intercollegiate IWL Committee designed and performed an online questionnaire.

\section{METHODS}

A web based online survey was designed to look at how the working lives of hospital doctors in both training and nontraining grades could be improved. The survey was widely advertised-for example, in medical journals, on medical
Royal College websites, and by the Intercollegiate IWL Committee members. A paper based version of the survey was also available on request. The survey was live for a six week period (31 March to 14 May 2004). All data were collected, held, and analysed in accordance with the Data Protection Act, with the actual data available only to the data analysis group of the Intercollegiate IWL Committee.

The survey collected demographic data on position within the NHS, gender, and ethnic group.

Survey participants were asked to select five from the 35 IWL factors offered or record, in free text, what they believed would most improve their working lives (box 1). They were then asked to rank the five factors in order of importance ( 1 being the most important, 5 being the least).

\section{Analysis}

Respondents were classified according to NHS grade. Analysis of the "top five" IWL factors for each grade was selected by assigning a score of 3, 2, and 1 according to respondents' first, second, and third IWL choices. Only the first three choices were weighted for this analysis of the whole cohort of hospital grades.

Abbreviations: IWL, Improving Working Lives; PRHO, preregistration house officer; $\mathrm{SHO}$, senior house officer 
Box 1: The nine broad category headings used to group 35 individual options to improve working lives of hospital doctors

(1) Improved support

- Medical support (medically trained personnel).

- Clinical, non-medical support (for example, nursing staff).

- Non-clinical support (for example, secretarial or managerial).

- Better education/training.

- Better IT support.

- Childcare facilities.

- Carer facilities.

(2) Improved environment

- Improved office accommodation.

- Improved teaching facilities.

- Dedicated parking.

(3) Improved access to advice/mentoring/coaching, etc

- Medical careers advice (for example, how to become a general practitioner).

- Careers counselling/guidance (for example, what specialty might suit me).

- Mentoring.

- Coaching.

- Improved occupational health services.

- General counselling services.

(4) Improved access to flexible or part time opportunities

- Training in general.

- Training in chosen specialty.

- Working.

- Retirement.

- On-call arrangements.

(5) Improved attitudes to part time or flexible working or training

- Medical colleagues.

- Medical institutions.

- Managers.

- The NHS in general.

(6) Improved opportunities to develop

- To change career choice.

- To develop new skills.

(7) Improved working relationships with

- Medical colleagues.

- Other health professionals.

- Managerial colleagues.

- Better team working in general.

(8) Improved career breaks

- Sabbatical leave.

- Unpaid leave.

- Development leave.

(9) An improvement not covered by the above headings

- Other, free text.
The fourth and fifth choices tended to be spread over a wider range and will be used for future subanalysis involving individual grades and specialties.

The total scores for each of the 35 potential IWL choices were then collated and the top five IWL factors for each grade, ranked by score were produced.

Comparison of IWL choices across grades was made. Further analysis examined the influence of specialty, ethnic origin, and gender on these choices.

The free text provided in the ninth choice "Other" was grouped under broad headings for each grade of doctor.

Of the 1843 respondents, $30(2 \%)$ provided insufficient data to be included. A further 5\% were excluded as they were not currently working within the NHS (64 medical and dental students, 22 doctors working outside the NHS, and nine retired doctors). Of the remaining respondents, 1603 $(87 \%)$ were working in secondary care and $115(6 \%)$ were from primary care.

The Committee confined the analysis to secondary care as it was felt it was unable to include a reasoned analysis of primary care responses.

\section{RESULTS}

The 1603 hospital doctors who completed the questionnaire were 709 consultants (47\%), 586 specialist registrars (37\%), 194 senior house officers (SHOs; 12\%), 19 preregistration house officers (PRHOs; 1\%), 71 staff grade doctors/clinical assistants (4\%), and 24 associate specialists (2\%). The overall top five IWL choices by grade are shown in table 1. SHO and PRHOs have been analysed as one group and the staff and associate specialists group included staff grades, clinical assistants, and associate specialists.

\section{Analysis of the top five IWL choices (table 1)}

Various aspects for improved support were given as the top four IWL choices for consultants with improved non-clinical support-that is, administrative or managerial support being their first IWL choice. Second and third choices were for medical support-that is, support from doctors and clinical, but non-medical support, for example, from nurses. Improved IT support was their fourth choice.

Improved support for education and training was the first IWL choice for doctors in training (PRHOs, SHOs, and specialist registrars) and the staff and associate specialists group. Mentoring and non-clinical support were in the top five choices of all these grades. PRHOs and SHOs identified the need for clinical, non-medical support and specialist registrars identified the need for improved childcare.

\section{Analysis of IWL choices according to specialty (tables 2 and 3)}

Specialty was given by 475 of the 709 consultants, 564 of the 586 specialist registrars, and 80 of the 95 staff and associate specialists. An analysis according to specialty was not undertaken for the staff and associate specialists because of the small numbers involved.

There were differences in IWL choice by specialty, although consultants were remarkably consistent with all specialties choosing the need for non-clinical support as the top IWL choice apart from anaesthetists. Anaesthetic consultants highlighted the need for flexible on-call arrangements and part time working as did specialist registrars in paediatrics, obstetrics and gynaecology, and medicine. Specialist registrars in paediatrics and obstetrics and gynaecology identified provision of childcare in their top five IWL choices. Opportunities to develop new skills were important to consultants and specialist registrars in the surgical specialties and to staff and associate specialists. Mentoring was included in the top 
Table 1 The top five IWL choices by grade of hospital doctor; weighted scores are given in parentheses after IWL choice

\begin{tabular}{|c|c|c|c|c|}
\hline Choice & Consultants & Specialist registrars & SHO/PRHO & Staff and associate specialists \\
\hline 1 & Non-clinical support (617) & Education/training (405) & Education/training (219) & Education/training (63) \\
\hline 2 & Medical support (448) & Child care (255) & Mentoring (87) & Other (48) \\
\hline 3 & Clinical non-medical support (341) & Mentoring (210) & Clinical, non-medical support (83) & To develop new skills (46) \\
\hline 4 & IT (269) & Non-clinical support (209) & Other (76) & Non-clinical support (42) \\
\hline 5 & Other (234) & Other (179) & Non-clinical support (74) & Mentoring (30) \\
\hline
\end{tabular}

five choices for specialist registrars in medicine and obstetrics and gynaecology.

IWL choices among male and female doctors (table 4) Similar choices were made by male and female consultants, SHO/PRHOs, and staff and associate specialists. By contrast the most important IWL factor among the 285 female specialist registrars was childcare support, which was not selected as one of the male specialist registrars' first five choices.

\section{IWL choices among black and minority ethnic doctors (table 5)}

Among the doctors surveyed, 326 (20\%) identified themselves as belonging to black and ethnic minority groups ( 58 consultants, 164 specialist registrars, 71 SHO/PRHOs, and 33 staff and associate specialists). Compared with the main cohort surveyed, the IWL choices are similar overall (see table 1). However, improved access to mentoring was selected by all grades as one of their five IWL choices.
Analysis of free text given by the different NHS grades The free text comments were read by three members of the IWL data analysis group ( $\mathrm{S}-\mathrm{AB}, \mathrm{AD}, \mathrm{JC}$ ). Comments that fell outside the 35 IWL listed options were grouped under headings for each grade. Consultants wanted a reduction in the political and target driven environment, a reduction in bureaucracy and commented on dissatisfaction with support offered by Royal Colleges. Specialist registrars were concerned over the implementation of the European working time directive and pay issues. SHOs/PRHOs felt there was a lack of recognition for work done and that annual and study leave was inflexible including raising concerns over the funding of education and training courses. Staff and associate specialists commented on a lack of recognition and respect from colleagues.

\section{DISCUSSION}

NHS hospital doctors want better support to improve their working lives. The type of support required varies depending on the stage doctors are at in their careers but does not differ with ethnic origin.

Table 2 Top five IWL choices of consultants according to specialty; weighted scores are shown in parentheses after IWL choice

\begin{tabular}{clllll}
\hline & Surgical & Medical & $\begin{array}{l}\text { Obstetrics and } \\
\text { gynaecology }\end{array}$ & Paediatrics & Anaesthetics \\
\hline $\begin{array}{l}\text { Total } \\
\text { Female (\%) }\end{array}$ & 155 & 58 & 40 & 42 & 53 \\
Choice & $22(14)$ & $27(47)$ & $19(48)$ & $18(43)$ & 19 (39) \\
1 & Non-clinical support (61) & Non-clinical support (55) & Non-clinical support (44) & Non-clinical support (14) & $\begin{array}{l}\text { Part time and flexible on- } \\
\text { call arrangements (30) }\end{array}$ \\
2 & $\begin{array}{l}\text { Clinical non-medical } \\
\text { support (38) }\end{array}$ & Medical support (43) & Medical support (33) & $\begin{array}{l}\text { Clinical non-medical } \\
\text { support (12) }\end{array}$ & Non-clinical support (29) \\
3 & Medical support (36) & $\begin{array}{l}\text { Clinical non-medical } \\
\text { support (35) }\end{array}$ & To develop new skills (18) & IT (12) & IT (28) \\
4 & IT (33) & IT (15) & Medical support(10) & Team work (25) \\
5 & To develop new skills (32) & Other (20) & Other (12) & Sabbatical leave (9) & Medical support (23) \\
\hline A total of 127 consultants were in other specialties; 234 consultants did not give their specialty. & & \\
\hline
\end{tabular}

Table 3 Top five IWL choices among specialist registrars in the five largest specialty groups; weighted scores are shown in parentheses after IWL choice

\begin{tabular}{|c|c|c|c|c|c|}
\hline & Surgical & $\begin{array}{l}\text { Obstetrics and } \\
\text { Gynaecology }\end{array}$ & Paediatrics & Medicine & Dental \\
\hline Total & 208 & 112 & 79 & 37 & 39 \\
\hline Female (\%) & $50(24)$ & $77(69)$ & $56(71)$ & $21(57)$ & $23(59)$ \\
\hline Flexible trainees & 4 & 2 & 12 & 4 & 2 \\
\hline \multicolumn{6}{|c|}{ Choice } \\
\hline 1 & Education/training (154) & Education/training (118) & Child care (55) & Non-clinical support (24) & Education/training (26) \\
\hline 2 & Non-clinical support (85) & To develop new skills (71) & $\begin{array}{l}\text { Clinical non-medical } \\
\text { support (37) }\end{array}$ & Mentoring (17) & Non-clinical support (20) \\
\hline 3 & Other (76) & Mentoring (64) & Non-clinical support (29) & IT (14) & Child care (17) \\
\hline 4 & IT (72) & Child care (63) & $\begin{array}{l}\text { Office and } \\
\text { accommodation (29) }\end{array}$ & $\begin{array}{l}\text { Part time and flexible on- } \\
\text { call (14) }\end{array}$ & $\begin{array}{l}\text { Clinical non-medical } \\
\text { support (16) }\end{array}$ \\
\hline 5 & To develop new skills (52) & $\begin{array}{l}\text { Part time and flexible } \\
\text { training (48) }\end{array}$ & $\begin{array}{l}\text { Part time and flexible } \\
\text { on-call (27) }\end{array}$ & Team work (14) & To develop new skills (15) \\
\hline
\end{tabular}


Table 4 Demographic data for the 1603 respondents to the online IWL survey; the top five IWL choices are shown by gender within the different grades; weighted scores are shown in parentheses after IWL choice

\begin{tabular}{|c|c|c|c|c|c|c|c|c|}
\hline & \multicolumn{2}{|c|}{ Consultants $(706)^{*}$} & \multicolumn{2}{|c|}{ Specialist registrars $(584) \dagger$} & \multicolumn{2}{|l|}{ SHO/PRHO (213) } & \multicolumn{2}{|c|}{$\begin{array}{l}\text { Staff and associate specialists } \\
\text { (95) }\end{array}$} \\
\hline & Male & Female & Male & Female & Male & Female & Male & Female \\
\hline Total & 458 & 248 & 299 & 285 & 104 & 109 & 46 & 49 \\
\hline $\begin{array}{l}\text { Working } \\
\text { part time }\end{array}$ & 1 & 2 & 3 & 29 & 1 & 4 & 0 & 1 \\
\hline \multicolumn{9}{|l|}{ Choice } \\
\hline 1 & $\begin{array}{l}\text { Non-dinical } \\
\text { support (382) }\end{array}$ & $\begin{array}{l}\text { Non-clinical } \\
\text { support (231) }\end{array}$ & $\begin{array}{l}\text { Better education/ } \\
\text { training (228) }\end{array}$ & Childcare (180) & $\begin{array}{l}\text { Befter education/ } \\
\text { training (122) }\end{array}$ & $\begin{array}{l}\text { Better education/ } \\
\text { training (97) }\end{array}$ & $\begin{array}{l}\text { Better education/ } \\
\text { training (42) }\end{array}$ & $\begin{array}{l}\text { To develop } \\
\text { new skills (28) }\end{array}$ \\
\hline 2 & $\begin{array}{l}\text { Medical } \\
\text { support (297) }\end{array}$ & $\begin{array}{l}\text { Medical support } \\
\text { (148) }\end{array}$ & $\begin{array}{l}\text { Non-clinical } \\
\text { Support (132) }\end{array}$ & $\begin{array}{l}\text { Better education/ } \\
\text { training (174) }\end{array}$ & $\begin{array}{l}\text { Clinical, non- } \\
\text { medical support } \\
\text { (44) }\end{array}$ & $\begin{array}{l}\text { Clinical, non- } \\
\text { medical support } \\
\text { (39) }\end{array}$ & $\begin{array}{l}\text { Clinical, non- } \\
\text { medical support } \\
\text { (25) }\end{array}$ & Other (25) \\
\hline 3 & $\begin{array}{l}\text { Clinical, non- } \\
\text { medical } \\
\text { support (224) }\end{array}$ & $\begin{array}{l}\text { Clinical, non- } \\
\text { medical support } \\
\text { (115) }\end{array}$ & $\begin{array}{l}\text { To develop new } \\
\text { skills (125) }\end{array}$ & Mentoring (122) & $\begin{array}{l}\text { To develop new } \\
\text { skills (39) }\end{array}$ & Mentoring (50) & Other (23) & $\begin{array}{l}\text { Non-clinical } \\
\text { Support (24) }\end{array}$ \\
\hline 4 & $\begin{array}{l}\text { IT support } \\
\text { (192) }\end{array}$ & Other (87) & Other (122) & $\begin{array}{l}\text { Training in } \\
\text { chosen specialty } \\
\text { (100) }\end{array}$ & Mentoring (37) & Other (39) & $\begin{array}{l}\text { Non-clinical } \\
\text { support (18) }\end{array}$ & IT support (22) \\
\hline 5 & $\begin{array}{l}\text { To develop } \\
\text { new skills } \\
\text { (162) }\end{array}$ & $\begin{array}{l}\text { IT support (76); } \\
\text { flexible on-call } \\
\text { arrangements } \\
(76)\end{array}$ & $\begin{array}{l}\text { Improved office } \\
\text { accommodation } \\
\text { (105) }\end{array}$ & $\begin{array}{l}\text { To develop new } \\
\text { skills (89) }\end{array}$ & Other (33) & $\begin{array}{l}\text { Training in } \\
\text { general (35) }\end{array}$ & $\begin{array}{l}\text { To develop new } \\
\text { skills (18) }\end{array}$ & $\begin{array}{l}\text { Better } \\
\text { education/ } \\
\text { training (21) }\end{array}$ \\
\hline
\end{tabular}

Previous publications have looked at why doctors are unhappy, but to our knowledge this is the first published national survey of hospital doctors where they are asked what would improve their working lives. ${ }^{23}$

The overwhelming message from consultants is that they require additional support with the first four IWL choices being about this issue. More non-clinical-that is, administrative and managerial—support was a consistent first IWL choice across all specialties, except anaesthetic consultants who placed it second. This finding is, perhaps, unsurprising, given the greater administrative load required in a target driven, consultant led, and more open working environment. The forthcoming "agenda for change" is likely to have a profound effect on NHS administrative and clerical staff careers, with the potential for the role of the medical secretary to be downgraded. ${ }^{45}$ As well as typing, medical secretaries have an important supportive clinical role liaising with patients, families, and other health care professionals and a vital administrative role in organising the service. Care needs to be taken to ensure that consultant support is not diminished as a result of "agenda for change" when it clearly needs to be enhanced.
Other support needed by consultants for their working lives to be improved is that provided by medically trained personnel, and from clinically, but not medically trained personnel. Reliance on other trained staff has increased as the day-to-day service support from trainee doctors has decreased due to the European working time directive at the same time as clinical workloads have increased.

In recent years non-medical clinical personnel roles have expanded to provide high levels of technical support-for example, nurse endoscopists, pharmacy technicians, and transplant coordinators. PRHOs and SHOs also identified a need for these roles and they will need to expand further if a workforce adequate to provide good patient care is to be provided by the NHS. Changes to service provision under the "hospital at night" project are already working in some hospitals and may be more widely introduced. ${ }^{6}$

IT support is also important. Clinical governance and annual appraisal require accurate recording of clinical data, both of which are dependent on good IT support. ${ }^{7}$ Emails, now the accepted means of communication between multiprofessional and multisite teams, are increasing in number and many require an immediate response. IT now underpins

Table 5 Top five IWL choices among 326 black and minority ethnic (BME) doctors according to grade; weighted scores are shown in brackets after IWL choice

\begin{tabular}{|c|c|c|c|c|}
\hline & Consultants & Specialist registrars & SHO/PRHO & $\begin{array}{l}\text { Staff and associate } \\
\text { specialists }\end{array}$ \\
\hline $\begin{array}{l}\text { BME doctors out of total } \\
\text { specifying an ethnic group } \\
(\%) \\
\text { Choice }\end{array}$ & $58 / 675(9)$ & $164 / 569(29)$ & $71 / 202$ (35) & $33 / 85$ (39) \\
\hline 1 & Non-clinical support (59) & $\begin{array}{l}\text { Better education/training } \\
\text { (113) }\end{array}$ & Better education/training (77) & $\begin{array}{l}\text { Better education/training } \\
\text { (35) }\end{array}$ \\
\hline 2 & Medical support (33) & Childcare facilities (89) & Improved teaching facilities (34) & Mentoring (15) \\
\hline 3 & To develop new skills (28) & Mentoring (89) & Clinical, non-medical support (31) & Other (14) \\
\hline 4 & Mentoring (23) & To develop new skills (72) & Mentoring (27) & $\begin{array}{l}\text { Clinical, non-medical } \\
\text { support (1 } 1 \text { ) }\end{array}$ \\
\hline 5 & $\begin{array}{l}\text { Clinical, non-medical } \\
\text { support (20) }\end{array}$ & Non-clinical support (56) & Careers counselling/guidance (25) & $\begin{array}{l}\text { Improved teaching facilities } \\
\text { (11) }\end{array}$ \\
\hline
\end{tabular}


communication, and access to good IT support is imperative for doctors to work safely and efficiently.

All other grades of doctor apart from consultants put education and training as the priority factor to improve their working lives. The European working time directive has resulted in the working lives of junior doctors becoming fragmented with reduced opportunities for bedside clinical teaching from senior staff.

Staff and associate specialists, unlike those in recognised training posts, do not have ring fenced time for education and training but are required to participate in continuing medical education for appraisal and General Medical Council revalidation. The opportunity to develop new skills was their third choice. Used correctly, an annual appraisal should provide staff and associate specialists with the opportunity to discuss their own personal and professional development needs, career paths, and goals with a relevant consultant and manager. ${ }^{78} \mathrm{~A}$ number of proposed recommendations were also made in the 2003 consultation on non-consultant career grade doctors and if implemented these would improve the working lives of staff and associate specialists. ${ }^{9}$

Comparison across specialties indicated that there had been a high return from specialist registrars in the surgical specialties (surgery and obstetrics and gynaecology). Surgical training has been affected by the reduction in working hours after introduction of the "New Deal", the European working time directive, and consequently full/partial shift working patterns. ${ }^{10}$ Training in surgical and other skill based specialties require structured supervised operating time. The Royal College of Surgeons of England has calculated that the number of hours available for training and gaining experience pre-Calman was around 30000 . This will reduce to less than 10000 after the introduction of the European working time directive and is likely to fall to just over 6000 hours if the Modernising Medical Careers proposals to shorten specialist training are adopted. ${ }^{11}{ }^{12}$

It is therefore unsurprising that improved support for education and training is the most important IWL issue for today's specialist registrars from the surgical specialties. The Royal Colleges will need to ensure that training opportunities are maximised including use of skills laboratories, simulators, dedicated training clinics and lists to ensure that tomorrow's surgeons can acquire a similar range and level of skills as those trained a decade ago.

Improved support for childcare was the second IWL choice among the specialist registrars overall and the top choice for paediatrics, a specialty with a high proportion of female specialist registrars. Under the IWL initiative there have been improvements in childcare with increased hospital crèche facilities. However most hospital crèches still do not have opening hours that correspond to junior doctors shift patterns, especially early morning and evening work. It is to be expected that many doctors will start their families during their specialist registrar training as the median age for first pregnancy in the UK is now 27 years and for all births is 29 years old. ${ }^{13}$

Doctors with young children require robust access to high quality childcare facilities and, with full shift working patterns, this must be available both in and out of normal working hours.

The Calman reforms to specialist registrar training require that they change hospitals usually on a yearly basis. ${ }^{10}{ }^{14}$ This combined with the long journey times often involved has added to the difficulties of arranging local childcare.

Another consequence of specialist registrars having to change hospitals frequently is that they are no longer one consultant's responsibility.

Previously specialist registrars worked for three to five years with one team of consultants who individually or collectively provided mentoring and career support. This change is likely to have contributed to the specialist registrars third IWL choice for improved access to mentoring and this is an issue that postgraduate deans and specialist training committees should consider.

Today's medical workforce is increasingly female and with female medical students representing $62 \%$ of all Universities and Colleges Admissions Service places for medicine in the UK in 2003, women will represent an increasingly large proportion of the medical profession in the near future. ${ }^{15}$ This survey clearly shows that among female specialist registrars support for childcare is their most import IWL issue. As these specialist registrars become consultants, the NHS of the future will need to expand and adapt its childcare facilities to accommodate an increasing female workforce with childcare responsibilities.

The 1603 hospital doctors who took part in this survey were largely representative of the NHS secondary care workforce. ${ }^{16}$

The survey cohort had proportionally more surgical and paediatric doctors than Department of Health census data of doctors in England in September 2003, and this in part is likely to be because the host website is that of the Royal College of Surgeons. ${ }^{16}$

As a result there were slightly more women across all grades and fewer black and minority ethnic specialist registrars than would be expected. Despite these differences the percentages of black and minority ethnic consultants and those working part time including flexible training were similar.

The proportion of black and minority ethnic doctors surveyed among the combined grades of SHO and PRHO and the staff and associate specialist doctors are similar to the data given by the Department of Health individually for SHO, PRHO, staff grades, clinical assistants, and associate specialist grades. ${ }^{16}$

Although this was an online survey, it was advertised in print and a print copy could be obtained. IT forms an essential part of the working life of all grades of doctors and it is unlikely that the results have been affected by the mode of survey.

Of the 1603 respondents, 1383 were working in England. The respondents represent $2 \%$ of the total of 78310 doctors. ${ }^{16}$

This survey was done over a six week period and the number of doctors would have been increased if it had been open for longer.

Currently there are many changes in the NHS with the new consultant contract, European working time directive, and Modernising Medical Careers including setting up of foundation programmes for all graduates and run-through grades for specialties. ${ }^{17}$ This change represents opportunities to improve the working lives of doctors by providing the needed support outlined by the IWL online questionnaire. It is important to think of what consultants require, junior doctors in training and staff and associate specialist grades need, and to consider specialty requirements. The increasing female workforce should not be forgotten with opportunities for part time and flexible working patterns and increased childcare provision required.

It is vital that doctors are regularly consulted as to what they feel will improve their working lives and a follow up study is planned in three years' time.

The findings of this survey will influence the setting of IWL standards required by NHS trusts to obtain "Practice Plus" status. However, for the working lives of doctors in secondary care to be improved NHS trusts, deaneries, and Royal Colleges need to endorse policies that will bring about the necessary changes. 


\section{ACKNOWLEDGEMENTS}

The Intercollegiate IWL committee in addition to the data analysis group comprises the following members: Dr Jane Barrett (Faculty of Oncologists), $\mathrm{Mr}$ Alan Dickson (Royal College of Surgeons, Edinburgh), Dr Paola Domizio and Dr Clair du Boulay (Royal College of Pathologists), Dr Alicia Etchegoyen (Royal College of Psychiatrists), Dr Robin Farman (Faculty of Occupational Medicine), Ms Susan Hooper (Faculty of Dental Surgery), Dr Sarah Jarvis (Royal College of General Practitioners), Dr Alison Jones (Royal College of Physicians, Edinburgh), Dr Anne May (Royal College of Anaesthetists), Ms Heather Mellows (Royal College of Obstetricians and Gynaecologists), Ms Anne Moore (Royal College of Surgeons of England), Ms Susan Morris (Royal College of Radiologists), Ms Caroline Mortimer (IWL Adviser), Ms Fiona O'Sullivan (Royal College of Ophthalmologists), Dr Renee Page (Royal College of Physicians), Dr Anna-Maria Rollin (Royal College of Anaesthetists), Dr Jackie Taylor (Royal College of Physicians and Surgeons, Glasgow), Ms Margaret Wilson (Faculty of Dental Surgery), Ms Elizabeth Eddy (Department of Health), and Ms Debbie Mellor (Department of Health).

The Committee would like to thank the members of the Royal College of Surgeons of England web team for their assistance in designing and launching the survey.

We would also thank all doctors who completed the online survey.

\section{Authors' affiliations}

A Dornhorst, IWL representative from the Royal College of Physicians of London, London, UK

J Cripps, Secretary to the Intercollegiate IWL Committee, Royal College of Surgeons of England, London, UK

H Goodyear, IWL representative from Royal College of Paediatrics \&

Child Health, London, UK

J Marshall, IWL representative from Royal College of Psychiatrists, London, UK

E Waters, IWL Champion for Doctors, c/o Royal College of Surgeons of England, London, UK

S-A Boddy, IWL representative from the Royal College of Surgeons of England and Chair of the Intercollegiate IWL Committee, London, UK
Funding: The Department of Health provided funding to set up the IWL Committee who advertised and drew up the survey. The funding source had no involvement in this survey, the items included, or the analysis of the results.

\section{REFERENCES}

1 Department of Health. Improving working lives for doctors. London: DoH, 2001.

2 Smith R. Why are doctors so unhappy? BMJ 2001;322:1073-4.

3 NHS Confederation. The problem of unhappy doctors: what are the causes and what can we do? London: NHS Confederation, 2002.

4 Department of Health. Agenda for change-modernising the NHS pay system. London: DoH, 2004

5 Department of Health. Agenda for change. Proposed agreement. London: DoH, 2004.

6 Modernisation Agency. Hospital at night. Redefining out-of-hours medical cover for hospitals. London: Modernisation Agency, 2004.

7 General Medical Council. General Medical Council annual review 2003/4 London: GMC, 2004.

8 Department of Health. Non-consultant career grade doctors: annual appraisal. London: DoH, 2003.

9 Department of Health. Choice and opportunity. Modernising medical careers for non-consultant career grade doctors. London: DoH, 2003.

10 Mather H, Pounder R, Loveday D, et al. Implementation of the European working time directive by August 2004 for specialist registrars in acute hospital medicine. R Coll Physicians Lond Commentary 2003 (suppl 1):1-29.

11 Chesser S, Bowman K, Phillips H. The European working time directive and the training of surgeons. BMJ Careers Focus 2003;325:69.

12 Department of Health. Modernising medical careers. The response of the four UK Health Ministers to the consultation on unfinished business: proposals for reform of the senior house officer grade. London: DoH, 2004.

13 Birth Statistics. Review of the Registrar General on births and patterns of family building in England and Wales, 2002. London: Office for National Statistics, 2004.

14 Calman report. Hospital doctors: training for the future. The report of the Working Group on Specialist Medical Training. London: HMSO, 1993.

15 BMA Board of Education. The demography of medical schools: a discussion paper. London: British Medical Association, 2004.

16 NHS Hospital, Public Health Medicine and Community Health Services. Medical and dental staff in England: 1993-2003. London: DoH, 2004.

17 Department of Health. Postgraduate medical education and training. The Postgraduate Medical Education and Training Board-policy statement. London: DoH, 2002. 